\title{
THE BOKA KOTORSKA: A VERNACULAR RESPONSE TO SUSTAINABLE URBAN ENVIRONMENTS
}

\author{
Alan Derbyshire ${ }^{\mathrm{a}}$, Tatjana Kecojevic ${ }^{\mathrm{b}}$ \\ University of Central Lancashire, UCLan, Preston, PR1 2HE, UK \\ E-mail: aakderbyshire@uclan.ac.uk (correspondingauthor); ${ }^{\mathrm{t}}$ tkecojevic@uclan.ac.uk
}

Received 12 February 2014; accepted 15 May 2014

\begin{abstract}
This study focuses on the development of the Boka Kotorska region of Montenegro. As such it attempts to analyse the viability of sustainable development in the region and considers the role of vernacular architecture and ecology as contributory factors. The development of the tourist industry within Montenegro is a key element within the overall strategy for economic growth. This has obvious implications for the urban development of the case study area as uncontrolled deregulated expansion threatens the future viability of attempts to create genuine environmentally sensitive planning policies. Accordingly, this study raises and discusses many of the issues faced by stakeholders in implementing innovative spatial and architectural development.
\end{abstract}

Keywords: ecology, architecture, vernacular, spatial planning, sustainability, tourism.

Reference to this paper should be made as follows: Derbyshire, A.; Kecojevic, T. 2014. The Boka Kotorska: a vernacular response to sustainable urban environments, Journal of Architecture and Urbanism 38(2): 148-160.

\section{Intoduction}

The visual and formal homogenization of urban environments as a result of globalization is recognized as an obstacle to establishing genuine indigenous developments. The Montenegrin aim of developing the notion of 'Wild Beauty' reflects an understanding of the need to both preserve and create a distinguishable identity within the region. This is not a simple process; the interconnecting problems associated with globalization can greatly influence the character and cultural identity of future projects. As such, the situation Montenegro faces in establishing the concept of 'Wild Beauty' is to adapt to the challenge associated with these issues.

Montenegro is located in South-Eastern Europe sharing borders with Serbia, Bosnia and Herzegovina, Croatia, Albania and the Adriatic Sea (Fig. 1). The climate is Mediterranean on the coast with average temperatures of $27^{\circ} \mathrm{C}$ and alpine conditions prevailing in the mountains. Until 1992 Montenegro was part of former Yugoslavia before dissolution when it formed a loose federation with Serbia prior to 2006 when it formally declared its independence. The population is approximately 700,000 and the population density is 49.6 per sq $\mathrm{km}$ with $61.5 \%$ of the population living in urban areas (eStandardsForum 2010).

The Boka Kotorska is a large twisting bay in the South West of Montenegro and is lined with a number of towns and urban developments along its coastline (Fig. 2).

The Montenegrin government is committed to accession to the EU and as part of this process has made sustainable development a vital feature of its application.

This study focuses on the development of the Boka Kotorska region of Montenegro. Consequently, it attempts to analyse the viability of sustainable growth in the region and its relationship with spatial development and tourism. The contribution of Travel and Tourism to Gross Domestic Product is expected to rise from 20.8\% in 2009 to $25.6 \%$ by 2019 (US - Montenegro Business Council, 2012). Accordingly, the study reviews the contributory components of sustainable development, in this case ackowledged as the potential to establish a distinct regional identity and maintaining local cul- 


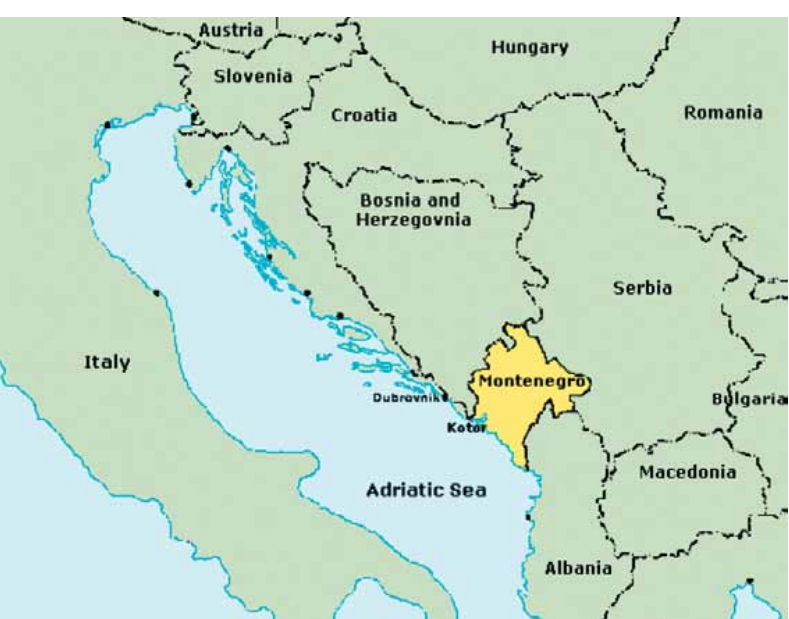

Fig. 1. Map of Former Yugoslavia

tural values. Establishing place based design solutions to ecological development in an expanding urban environment is a challenging task. Consequently, the prospective role of vernacular architecture and ecology as contributory components to achieving this objective is reviewed and examined in Section ("Vernacular architecture and ecology").

The study considers fundamental elements to the establishment of viable sustainable development within the Boka Kotorska and discuss the possibility of creative solutions to the goal of ecologically inspired design models.

The objective of full EU integration and commitment to become an eco state has underpinned governmental policies relating to many economic, social and environmental issues not least the specific matter of spatial growth and sustainable tourism. Montenegro's stated position on sustainability and ecology are unambiguously highlighted in the 2007 constitution document (Constitution of Montenegro 2007). However, the objective of being recognized as an ecological state does not just reflect Montenegro's attempt to create a distinctive identity as a result of its' relatively new found independence. In 1991 whist still a part of former Yugoslavia the constitution of the Republic of Montenegro declared itself to be an 'Ecological State' (Constitution of the Republic of Montenegro 1991).

With this in mind Section ("Environment, E.U. and wild beauty") of the paper reviews these commitments and evaluates the state of progress. The stated governmental objectives pertaining to sustainable tourism combined with significant foreign investment within the Boka Kotorska region represent a solid foundation for favourable sustainable urban developments. Accordingly, we attempt to examine the relationship between rhetorical ambition, practicalities and the relative success of implementation and good practice.

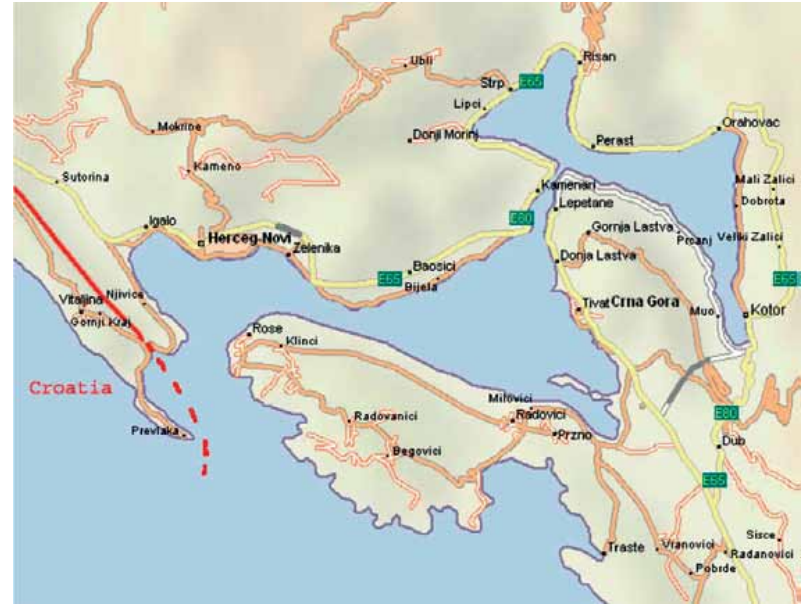

Fig. 2. Boka Kotorska Bay

An alternative response to the demands associated with increasing tourism on the development of architectural, cultural and urban spatial form is a key sustainability concern. How this is practically achieved is at the heart of the matter. In particular, the capacity for spatial expansion to reflect a distinguishable cultural dynamism whilst maintaining a coherent approach to the growth of ecologically inspired urban form.

In determining the sustainable future of the region, a creative reaction to change is a fundamental requirement to achieve a distinctive regional identity. Successfully negotiating the cultural diversity and expectations of local communities in regards to applying ecological and architectural design innovation is an enormously challenging process. Consequently, appropriate philosophical and practical responses are needed to properly facilitate the establishment of culturally sensitive design solutions. As such, Section ("Case studies and analysis") reviews individual responses to established frameworks through three case studies of varying range of scales and approaches.

Vernacular architecture and tradition is acknowledged and often cited as a desirable element in the objective of achieving a more sustainable urban form. However, this is not as marked in the adoption of vernacular ecologies within sustainable design processes. Correspondingly, this paper reviews the potential role of both approaches to the evolution of sustainable landscape and contextualises the promotion of the 'ecostate' as a tourist destination.

\section{Vernacular architecture and ecology}

Vernacular architecture and ecologies applied to contemporary architectural and landscape design projects offer the potential to establish genuine sustainable and culturally accessible alternatives to the 'one size fits all' 
association with globalization. Within the context of the Boka Kotorska, vernacular technologies and traditions should be viewed as a culturally inclusive element in the resilient development of the region and not as an architecturally deterministic antidote to global homogeny.

The definition of vernacular architecture is open to interpretation. Vernacular derives from the Latin vernaculus, meaning native, however vernacular generally refers to language or dialect. Paul Oliver suggests the word shelter as a more neutral term, emphasizing the common purpose of a structure or building (Oliver 2007). For most part however vernacular architecture is seen as a building or structure made by empirical builders without any input from architects. The reliance on limited local materials and resources meant that native craftsmen used inherited solutions that were efficient out of necessity. This often resulted in sophisticated and innovative building forms that were uniquely environmentally sustainable and culturally adaptive (Kazimee 2008).

Vernacular architecture and technologies can potentially contribute to the practical realization of innovative development projects concerned with creating more progressive and culturally empathetic design solutions. Using local materials and ecologies in the designing, planning and building process contributes to a more identifiable relationship with indigenous traditions, aesthetics and topography. This consequently creates a sense of ownership, care and sustainable heritage amongst communities. Much can be learned from vernacular forms in regards to responding to local culture and climates:

- Self organized as opposed to top down design,

- Influences the scale of potential developments,

- Pragmatic usage of traditional local materials,

- Channel cooling breezes through building,

- Capture and store rainwater,

- Effectively manage heat inertia and radiation,

- Establish visual/formal references to local tradition/culture.

The dynamic nature of vernacular forms and how such forms occur are largely determined by local and external factors. It is this ability to respond to vigorous change in an incremental manner that suggests a vernacular response provides a viable contribution to the objective of preserving a distinctive regional identity and culture.

The relationship between cultural identity and the rapidly evolving global and local influences over the urban spatial characteristics of the Boka Kotorska is a potential source of discord or opportunity. The challenge for stakeholders is to conceptualize regional identity and expression as a bold and inclusive cultural process. The connection between cultural conventions and regional environments are fundamental elements in vernacular architectural theory and philosophical reasoning.

As Heath obseves when contextualising the notion of place in response to the increasing external influences on the landscape at a global and local scale the challenge for vernacular traditions is to "conceptualize regional expression as an inclusive and dynamic cultural process". Such adjustments to architectural and landscape form are part of the activity of redefining cultural heritage that express an alternative account of "habitation and a new collective identity of place" (Heath 2007). The challenge for the architectural and planning professions from Heath's perspective is to either disregard "the extinct vernacular" or embrace the present state of multiple cultural identities, realities and "transformative states of social change".

\section{Vernacular form of the Boka Kotorska}

Within the Boka Kotorska as a whole the numerous rulers and administrators beginning with the Romans and Illyrians to Venetian rule and the Austro Hungarians have indelibly marked the local architecture. In general, typical Montenegrin houses are built from local stone with a ground floor, a loft and with a konoba (Kapetanovic 2006). Within urban settlements in the mountains surrounding the Boka Kotorska the most common characteristics of the houses are usually in rows lined on either side of the street with rectangular base, a ground and second floor separated with lines of "symmetrically distributed doors and windows" (Fig. 3). At the street level there were shops, bars and craftsman stores, with each house having a garden and a yard (Vuksanovic 2006). Traditional coastal architecture around the region of the Boka Kotorska are characterized by the use of "large or small ashlar limestone, either of local origin or imported from the Dalmation islands" (Fig. 4). The restoration and conservation of these traditional structures has in the past been hampered by damage as a result of the 1979 earthquake, vandalism and extraction of stone materials. Some owners it is alleged deliberately wait for the buildings to collapse in order that they are able to replace them with larger buildings This practice is an obvious concern regarding the desire to maintain an indigenous identity. The notion that vernacular architecture can contribute to the sustainable development of a region is manifest given the utilization of local materials, craftsmen and the maintenance of regional identities. Perhaps it is therefore not surprising that the reference to vernacular architecture is a distinctive feature of the promotional material for major ventures such as Porto Montenegro. 


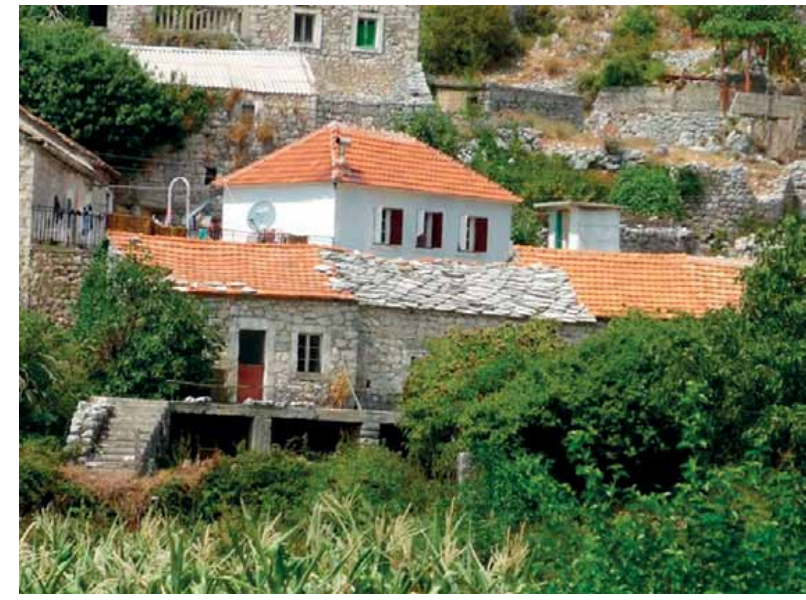

Fig. 3. Traditional Mountain Village House

The potential for future investment in Montenegro as a specific eco tourist destination had been recognised prior to recent high profile development projects such as the above mentioned 'Port of Montenegro'. In 2006 the United Nations Development program (UNDP) acknowledged the scope for growth within this sector comparing its potential to Costa Rica, a country noted for its success as an eco-state (UNDP 2006). The main threats to the sustainable management of the environment as acknowledged by the UNDP, are excessive and disorderly exploitation of natural resources, predominantly uncontrolled forest use, construction projects and conversion of agricultural land. In the coastal regions the fundamental sustainable management issues are related to the lack of adequate wastewater management systems and out of control construction enterprises. Unfavourable trends in the management of water, sewage and levels of air pollution that exceeds authorised standards are also matters for concern in certain municipalities. However, the government of Montenegro is committed to achieve the standards of an 'ecological state' and acknowledges the need to respond creatively to achieving sustainability while correspondingly reacting to national social and economic objectives.

The connection between architecture and nature has largely been regarded as two separate entities in that for most part architecture was designed without any reference to nature or ecology. Though architects are beginning to demonstrate a willingness to adopt more nature inspired approach to design and technology such as green roofs and living walls, the relative success is a source of debate amongst design professionals. Ian McHarg is uncompromising in his view of architecture in that "At best it's simply, obviously, a cosmetic addition. A sort of wallpaper on the surface

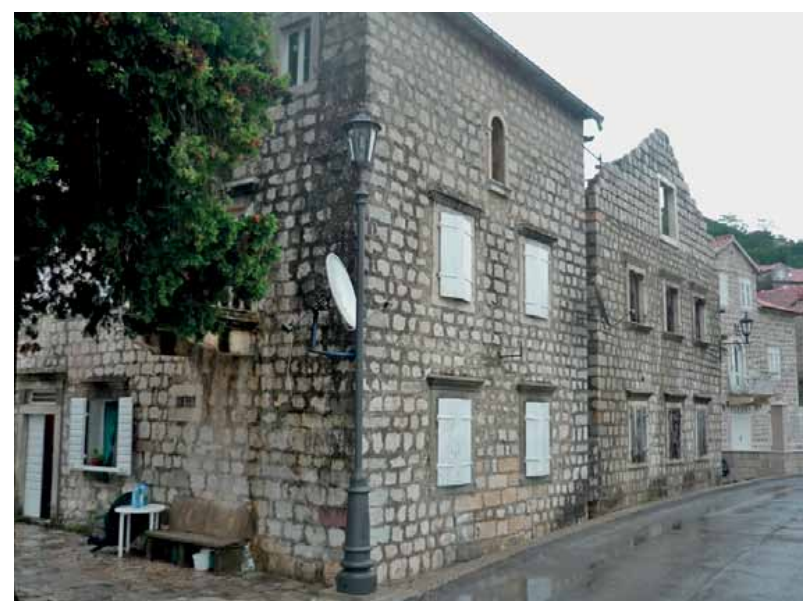

Fig. 4. Traditional Coastal House

which is subject only to style" (McHarg 1997). In his seminal book 'Design with Nature' McHarg reasons that nature has been designing far longer than man, therefore should be an integral part of the designing process. Architects and designers should know about the biological, physical and social impact of building in particular environments (McHarg 1967). The issue of creating a more ecological approach to design and building processes still remains a vexed matter despite a more progressive approach to ecology and design demonstrated by some architects. The growing awareness of environmental and global ecological issues has rekindled an appreciation of the landscape as a model for dynamic sustainable urbanism. The visual homogenization of urban developments is symptomatic of both hackneyed design orthodoxies and a tokenistic approach to sustainable practice.

The notion of the vernacular landscape within urban environments could be characterized as the working landscape "created out of nature and poverty". In other words the role of vernacular ecologies and the unpredictability of nature could be a source inspiration when designing a more sustainable urban form. Michael Hough concludes that traditional design values have not significantly contributed to the environmental health of cities and urban forms and maintains that urban designers, planners and architects have much to learn from the complexity of life forms as a basis for shaping human settlements. He acknowledges the validity of the vernacular landscapes of forgotten places, rooftops, pavements or wherever a foothold can be gained (Hough 1984). The concept of urban form being shaped by nature has been deliberated upon for several decades and despite this design outcomes have for most part reflected traditional modernist methodologies (Derbyshire 2010). There are however some 
examples of designers successfully applying some of the principles espoused by McHarg and Hough that have been well received and embraced by local inhabitants. This more environmentally sympathetic adoption of a nature inspired design strategies would appear to chime with the notion of 'Wild Beauty'. And through the application of local ecologies in urban development projects act to establish and maintain a distinctive regional identity.

\section{Outsiders and spatial planning}

The appeal of Montenegro as a tourist destination is relatively well known: varied coastline, reasonable prices, hospitality and a rich diversity of nature. These qualities are however undermined and potentially threatened by a general lack of awareness in terms of environmental knowledge, corruption, and "the relative financial weakness of the domestic stakeholders", resulting in the poor repair of tourist facilities in prime potential development areas. As a consequence, nearly all of the medium and premier structures and facilities have been built with foreign investment, and therefore are to a large extent governed from outside of Montenegro. The increase in investment and beneficial economic effects and growth in tourism are on balance regarded by Montenegrins as positive, but there is also concern at "the visible changes in the landscape" (Bickert et al. 2011). The uncontrolled expansion of settled areas and subsequent damage to the natural environment is an obvious concern given this is regarded as a fundamental feature of a sustainable Montenegrin tourist industry.

As a society Montenegro has undergone numerous transformations relating to spatial theory and applications, this state of flux is still perceptible and reflected in spatial planning processes. 'Outsiders' have historically influenced the evolution of urban form within Montenegro and it can be argued that the significant growths of tourist numbers (outsiders) are similarly affecting the development of spatial planning.

The Balkan Peninsula was deeply influenced by the arrival of the Turks at the end of the thirteenth century through the impact of Islamic planning and building conventions. For most part settlements had distinct structures including a central designated area for public activities such as trading posts, baths and coffee houses. Residencies were constructed around yards surrounded with high walls for privacy. This simultaneously contrasted with the influence of the Renaissance and baroque planning in coastal regions such as Perast and Herceg Novi at that time under the rule of the Venetian Republic. The Austro Hungarian occupation of much of the Balkan region contributed to more rigorous urban regulations, though Montenegro like Dubrovnik remained un conquered and therefore escaped externally imposed planning models.

Planning between the First and Second World Wars under the auspices of the new kingdom of Yugoslavia coincided with an increased migration from rural to urban areas. Throughout this period Yugoslavia adopted a more radical approach to town planning, embracing ideas from America, France and the U.K. such as the notion of the Garden City, Beaux-Arts and the City Beautiful. Post Second World War marked the replacement of more civic initiated approach to planning to a centralized planned economy focussing on the ascendancy of the collective interest in common with other Socialist republics. The Master Urban Planning Regulation was passed in 1949. However, despite the obvious association with the Eastern European/Soviet political ideology this was drafted following consultation with Western European countries such as Germany, Holland, Britain and France. As a consequence the legal frameworks underpinning the planning strategies were based on an amalgamation of Western models and the Yugoslav model of self-management.

The period from the 1960's to the late 1980's was characterized by an intensive drive in the preparation of plans for a diverse spatial range of projects on a macro, meso and micro scale from provinces to neighbourhoods to individual sites. This period of progressive and coherent planning objectives underpinned with multidisciplinary and cultivated ideas did not extend into the 1990's, the post communist period. This phase of development could be characterized as an age of stagnation and economic decline. Politics "took precedence over the attempts of planning practitioners to continue to guide urban development processes" (Nedovic-Budic, Cavric 2006).

Unsurprisingly, given the aims of the Montenegrin government to be acknowledged as an 'Eco-State' the current spatial plan provides a framework for spatial development including the defining of:

- General principles and objectives of spatial development based on sustainable development.

- Area and sub-area specific objectives of spatial development based on sustainable development.

- Sector and sub-sector specific objectives and principles as far as requirements of spatially related sustainable development are concerned.

- Guidelines to be considered in the elaboration of sector policies and more detailed planning documents on the national and local level.

- (Spatial Plan of Montenegro Until 2020, 2008). 


\section{Environment, E.U. and wild beauty}

As part of the procedure of the E.U. accession process the current MIPD document identifies several areas of assistance and support. Environmental and climate change figure prominently along with social and rural development amongst others. The environment is acknowledged as a main sector for Montenegro and its relationship with tourism as an important source of income. The Law on the Environment adopted by Montenegro is built upon Rio Declaration Principles and "recognises the importance of integrated environmental management, environmental protection and sustainable development" (RENA 2011).

The legislative principles that underpin Montenegros's commitment to environmental protection are embodied in the Constitution of Montenegro. Article 1 of the Constitution, which defines Montenegro as "civic, democratic and ecological state", proclaims that the "state is responsible for ensuring nature protection, healthy environment, sustainable development, balanced development of all of its regions and establishment of social justice" (The Constitution of Montenegro 2007).

The commitments to sustainable environmental development demonstrated by the Montenegrin government gives the impression of being authentic. In 2007 the Government established a National Strategy for Sustainable Development (NSSD). The NSSD emphasises the harmonisation of institutional and legal frameworks and is based on principles such as the Rio and Johannesburg Declarations as well as the EU Sustainable Development Strategy. Amongst other things the NSSD includes the key principles of (NSSD 2007):

- Integration of environmental issues into development policies;

- Access to information and access to justice;

- Internalisation of environmental costs through the implementation of the polluter/user pays principle;

- Participation of all actors/stakeholders in decision-making, consultations, dialogue and partnerships;

- Subsidiarity principle and correlation between local and global level.

Montenegro's aspiration for EU accession is also supported and strategically assisted by the United Nations Development programme (UNDP). In tandem with the EU, the UNDP aims to "promote sustainable development in economically viable, socially inclusive and environmentally friendly way". Significantly, the UNDP recognises the Montenegro Government pledge to achieve the standards of an 'ecological state' and acknowledges that future growth and prosperity will be reliant on an "export oriented tourist industry that is developed in a socially responsible way" (UNDP 2008).

The adoption of the notion of the 'Wild Beauty' brand was adopted and approved by the Montenegrin Parliament in 2008 as the strategy for tourist development to 2020. The brand evolved through its initial conception as a masterplan for sustainable tourism and is viewed as cooperative venture between governmental agencies and the private sector. Originally implemented as a road map plan for development of the Northern and Central regions of Montenegro the plan was eventually implemented at a national level. Ostensibly, the plan aims to foster outdoor tourism, develop connections between cultural and other economic regional assets to stimulate national and regional benefits.

Montenegro puts tourism at the heart of its drive for social and economic recovery and a strong destination brand is critical to establish itself in the international travel market (Vitic, Ringer 2007). In the general sense branding is intended to differentiate a product from comparable commodity from a competitor. Within the context of Montenegrin tourism, a destination brand is intended to influence visitors perceptions and represent the prevailing local values and cultural identity of its inhabitants. The destination brand is regarded as an important tool in international travel as a way of differentiating locally available services and products. Inevitably this process is made more complicated by globalization (Graburn 1995; Anholt 2006; Vitic, Ringer 2007). The potential of effective branding has encouraged Montenegrin governmental officials to acknowledge that a distinctive branding identity is an integral marketing tool. In attracting tourists to the Montenegro experience the country's biodiversity is seen as a distinctive characteristic when pursuing a more culturally and environmentally aware tourist demographic. With more than $40 \%$ of international travellers identifying themselves as eco-tourists the branding of 'Wild Beauty' builds on the legislative proclamation of Montenegro as an ecological state. Given that more and more tourists are now seeking attractions that are supportive of indigenous communities and environmentally sensitive, on the face of it puts Montenegro in a good position. As a consequence there is potential to increase the Montenegrin share of the market by 'building green' and implementing eco-friendly practices. Ultimately the long-term success of the branding will be determined by regulatory practice, public awareness and most importantly public acceptance (Vitic, Ringer 2007). 


\section{Case studies and analysis}

The key towns within Boka Kotorska are Kotor, Tivat and Hercig Novi and their surrounding regions. Accordingly, the case studies within this study highlight the relationship between urban expansion, spatial development, sustainability, ecology and their correlation to tourism. The identified case studies are intended to reflect a range of scales and responses to stated stakeholder policies, objectives and local implementation processes. As such, they vary in scale, ranging from 'high value' commercial developments to a small scale ecological business and family dwelling. The presented data is sourced from the local stakeholders used within the case studies and the Statistical Office of Montenegro (MONSTAT).

\section{Comercial development: Porto Montenegro - Tivat}

Tivat is one of the smallest boroughs in Montenegro, renown for its geo-strategic position and was a formative reason why the area developed as a main military navy base since the rule of the Austro-Hungarian Monarchy. The establishment of a military arsenal contributed to the creation of a village whose centre consequently developed around the military complex. The town has evolved during the twentieth century, in particular during the period between the Second World War and disintegration of Yugoslavia, during which the economic power of the military was a remarkable factor in creating strong migration to and subsequent population growth in Tivat.

As a town Tivat was built and developed spontaneously with the first urban plan dating only back to 1936 . The first contemporary urban and regional planning documents were made in the years after the catastrophic earthquake of 1979 (Tivat Borough 2011). The rapid development of Tivat's borough in recent years was an unforeseen phenomena when compared with the other more established towns of the Boka Kotor bay.

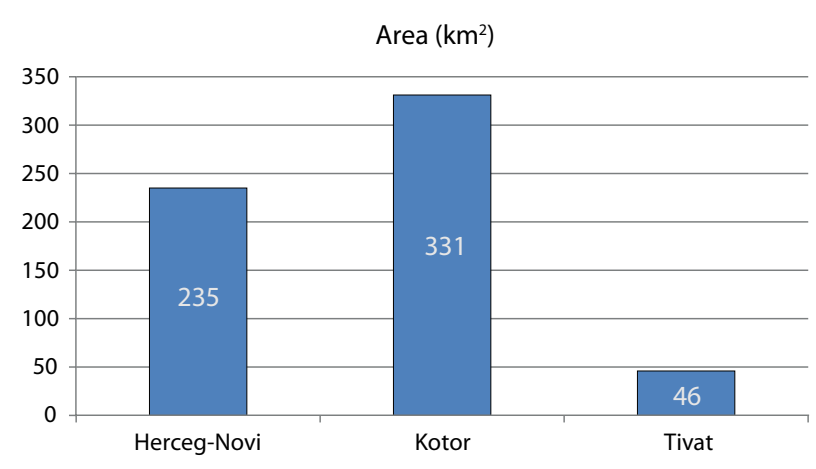

Fig. 5. Comparison of Boka Bay borough sizes
Tivat borough area is around 7 times smaller than borough of Kotor and is the $5^{\text {th }}$ of the size of borough of Herceg-Novi (Fig. 5). Nevertheless, in terms of number of approved construction applications closely follows recent trend of vigorous development of the Boka bay (Fig. 6). This can be explained by the redevelopment of the Naval base and subsequent foreign investment to develop an ex military facility into Porto Montenegro. Nautical tourism is recognised as a favoured type of tourism and the increasing demand created by this kind of tourism given the natural beauty of the coastline, is viewed as economically sustainable and environmentally desirable as the function of a marina is deemed to be less harmful than its previous function (Spatial Plan of Montenegro 2008).

Porto Montenegro's deep-water docks, according to its developer and main investor Peter Munk, are "twice as wide as anything in Monte Carlo" (McCall 2011). This statement offers an illuminating in-sight into the strategy for the promotion and marketing of Porto Montenegro. The former naval base has been developed and aggressively marketed to appeal to a 'jet set' clientele. On a visit to the resort Montenegro's then prime minister Milo Djukanovic stated "This is better than St. Tropez" and went on to say "Montenegro, will become one of the most elite tourist destinations in the world." (Thomas 2010).

Much of the architecture reflects the homogenised nature of aspiring developments aimed at the 'well heeled' with the obligatory designer retail outlets and luxury mixed use dwellings. The layout of the marina village is meant to replicate the style of a typical Montenegrin village "combining the sophistication of a super yacht destination with the picturesque vernacular of Montenegrin architecture" (Adam Consultancy 2010). To others however the village "atmosphere is Miami-meets-Venice with a healthy dollop of Soviet chic: models in thongs, men with spray tans, and fourstory apartment buildings" (Bloomberg 2011).

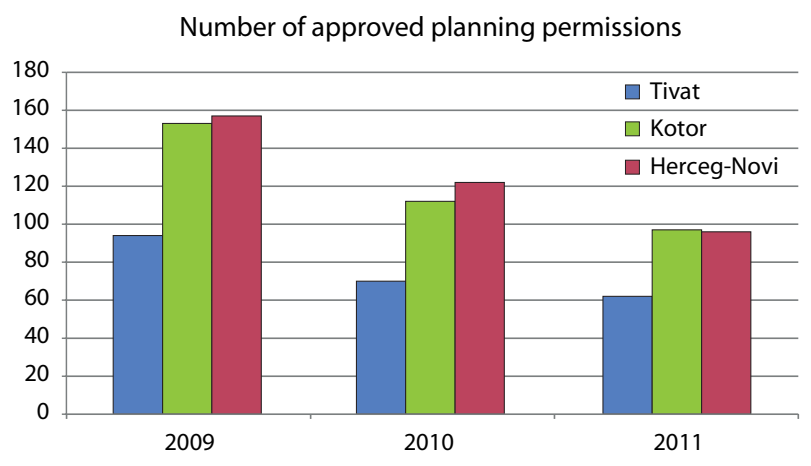

Fig. 6. Number of Approved Construction Applications 


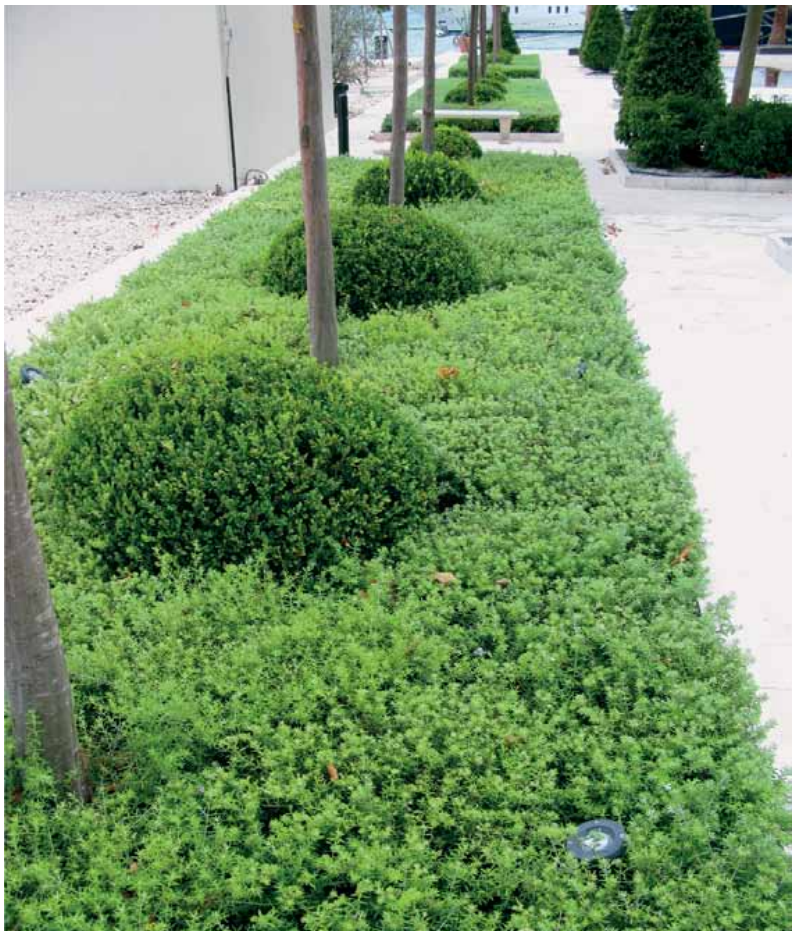

Fig. 7. Hard and Soft Landscaping

The design and implementation of trees and horticulture within the parcels of land between the buildings reflects a traditional adherence to modernist principles (Figs 7 and 8). As such, trees are planted in rows and appear to have been chosen for perceived aesthetic appeal rather than demonstrating an imaginative use of local species. The promotional literature boasts of the importation of "over a hundred full-grown palm trees from Uruguay" (Kingsmill 2011) and there is no clear evidence of the adoption of more ecologically inspired design principles as identified by McHarg (1967), Hough (1984, 1990), Corner (2007), Wu (2008), Derbyshire (2011).

\section{Comercial development: eco camp site - Malta, Herceg Novi}

The Eco-Camp site is situated on the North coast near the border with Croatia and was established within 8,000 square metres of rural land in 2010. The camp was created by two foreign European émigrés to Montenegro. The land was completely off grid with no supplied water, no electric and no sewerage system in place. The issue of providing a water supply was central to the development of the site given the obvious needs of tourists to shower and use toilet facilities etc. and also to supply an organic kitchen garden. In the absence of sewerage systems and a philosophical opposition to septic tanks the owners opted for the installation of

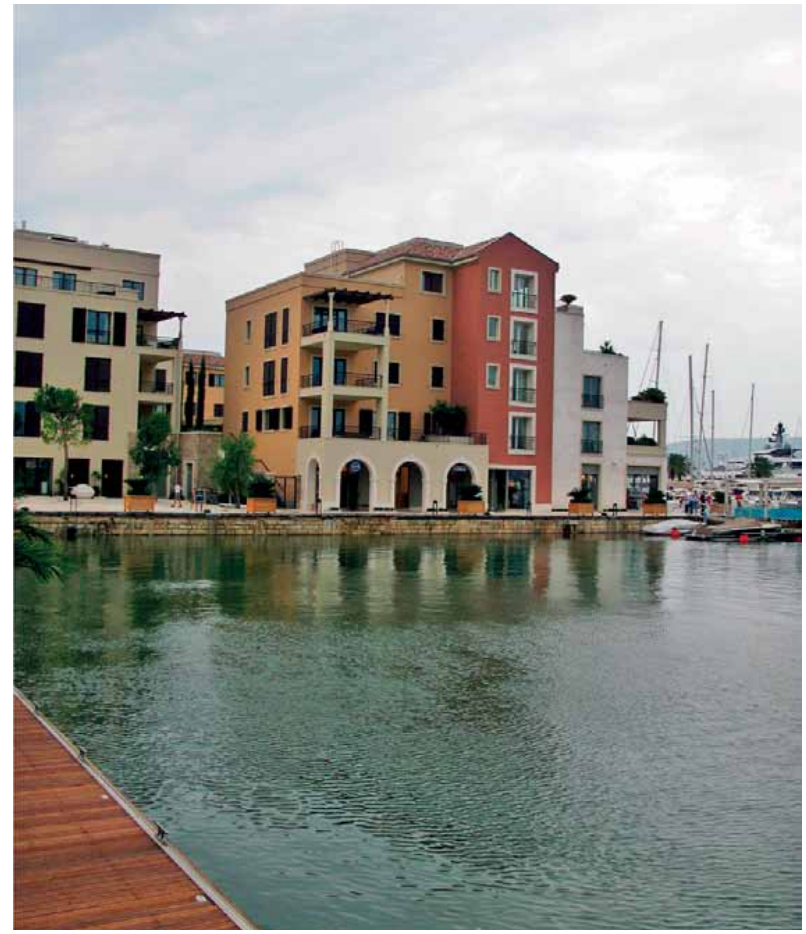

Fig. 8. Porto Montenegro Dwellings

compost toilets. This simple but effective technology was inspired by the Centre for Alternative Technology (CAT) and informed the development of the constructed shower and toilet block (CAT 2010).

To source a water supply the owners use a small petrol engine pump, to pump water from the spring adjacent to their land and fill a 45,000 litre water tank at the beginning of the season. This is currently the only source of water and it is estimated that they have extracted 150,000 litres of water from the spring in the last three years. This year for the first year they hope to capture some rainwater since acquiring a 1,000 litre tank that will fit under one of the down pipes coming off the guttering system on the communal building. The only source of electricity is from a small PV panel (Fig. 9) though the amount of power produced is negligible. It's enough to run $4 \times 3$ watt $12 \mathrm{v}$ DC fans 24 hours a day and keep a battery fully charged all summer. The fans are a vital component in the compost toilet and waterless urinal installations. As there is spare power in the battery, they hope to run an LED lighting system off it too this year. For the past 3 years they have relied on their $2.5 \mathrm{~kW}$ generator to provide power needs in the evening. They run it for 3-4 hours every evening to provide light, charge phones \& laptops etc. With increased use of solar lights and additional DC lighting system running off the battery they aim to reduce the use of the generator over time. 


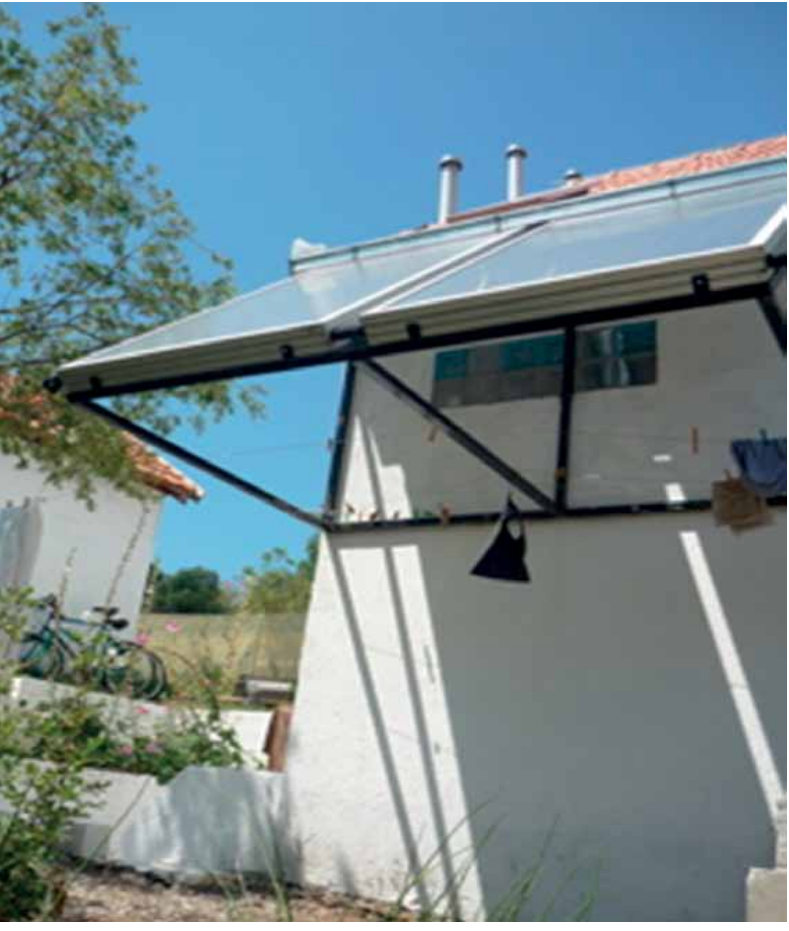

Fig. 9. Electricity generated by PV panels

There is a diversity of species of vegetation on the land such as Cypress, Oak, Pine, Bay, Juniper Elm and Hornbeam trees. Shrubs include Myrtle, Broom and Lavender amongst others and have added plants commonly found in the local region (Fig. 10). The kitchen garden also supports a herb garden including Thyme, Sage Oregano and Basil, the only exception to species not indigenous locally are a selection of northern European flowers, perennials and annuals, but as yet their response to the local climate has been difficult to gauge. Recycling is a significant matter for the owners and invariably attempt to solve problems by considering how to achieve their aim by recycling materials. Consequently, most of the finishing of the communal shower/toilet block by using waste and discarded materials such as floor tiles, off cut tile samples, glass bricks, scrap metal, bottles and several old iron baths provide a key component in the distribution of 'grey' water for irrigation. As the owners reflect, "we know we could have done more to reduce the impact of our campsite on the environment. Availability of materials and prohibitive costs are two big factors in Montenegro". Though they don't consider themselves to be 'eco warriors' they do regard their adopted environmental principles as "having greater empathy with nature".

The owners expressed a level of frustration with local governmental and civic authorities in terms of a perceived lack of understanding as to their contribution

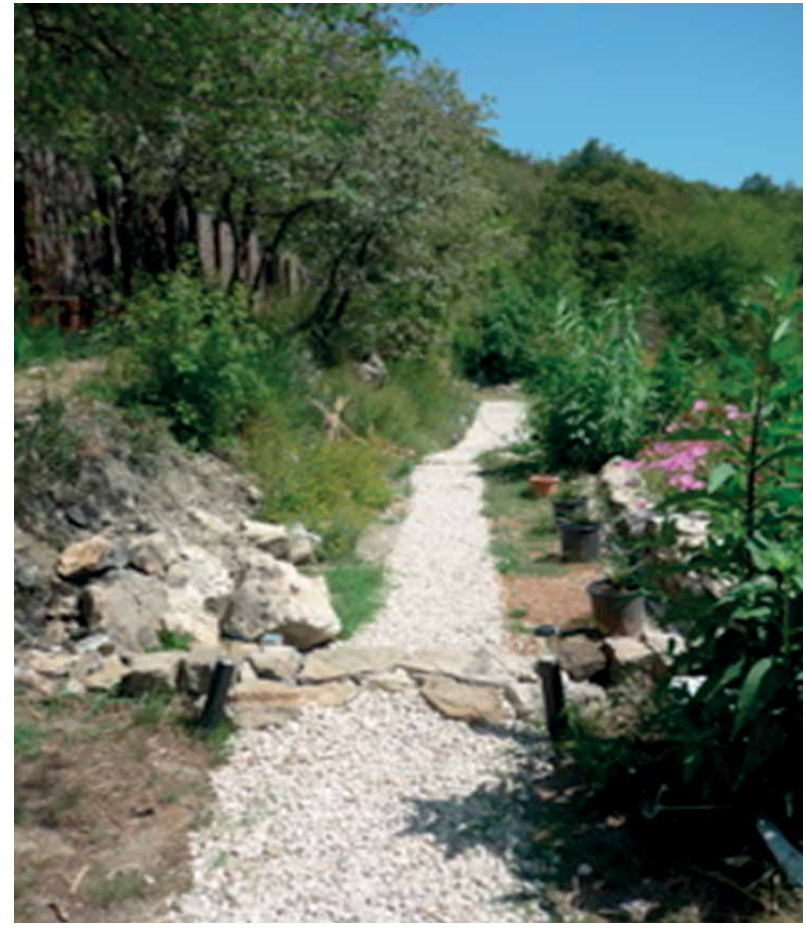

Fig. 10. Eco Camp Site Landscape

to the Montenegrin ecological objectives. There was also a level of disappointment expressed at the availability and prohibitive price of sustainable materials and technology amongst other things. To summarise, the main concerns can be characterised as:

- Sustainable materials are not available locally and the environmental impact of getting them into the country was considerable.

- Unavailability of local craftsmen to work with non-standard materials.

- No guidelines available in order to build with non-conventional materials such as straw bales or rammed earth. Standard earthquake tolerant building regulations are seemingly the only option.

- No local governmental initiatives or support offered or available.

- The perception that in terms of planning permission that "it's easier to beg for forgiveness than ask for permission" and in reality translates to "it's cheaper to pay for forgiveness than pay for permission".

\section{Dweling delevopment: local resident - Herceg Novi}

The subject is a University educated professional who moved to the area in 1998. She bought the $346 \mathrm{~m}^{2}$ plot of land in a semi urban area on a hillside over looking Herceg Novi in 2006 and has completed the first floor of a three-storey house that will be completed 
subject to available future funding. She occupied the dwelling in 2008 and she has studiously followed and implemented the local urbanisation and building planning regulations. Whilst preserving green space is viewed as an important feature of urban development as identified in Figure 11, the reccomended planted species are mostly for aesthetic purposes. Figure 12 highlight the scale of the difference between desirable,

Required Urban Parameters

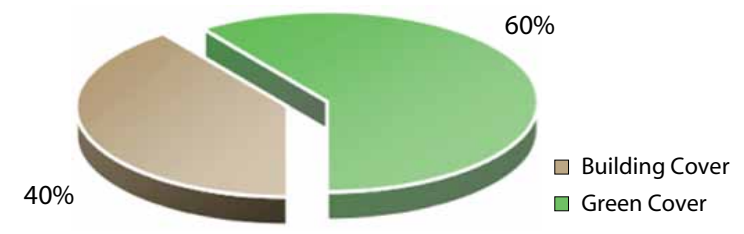

Fig. 11. Urban Development Parameters

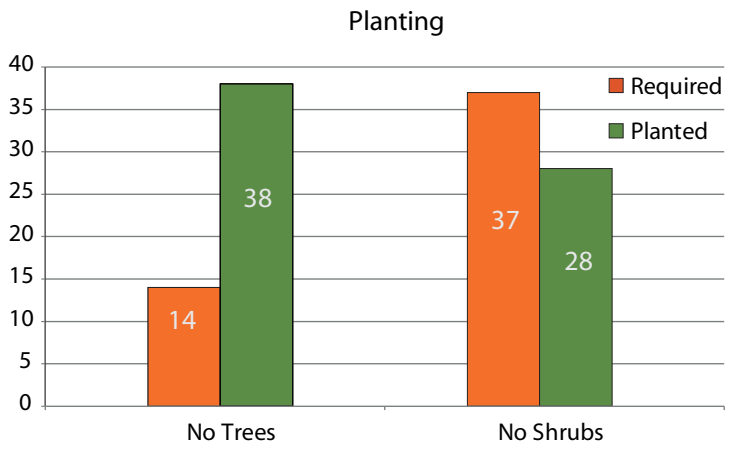

Fig. 12. Planting Requirement and Implementation

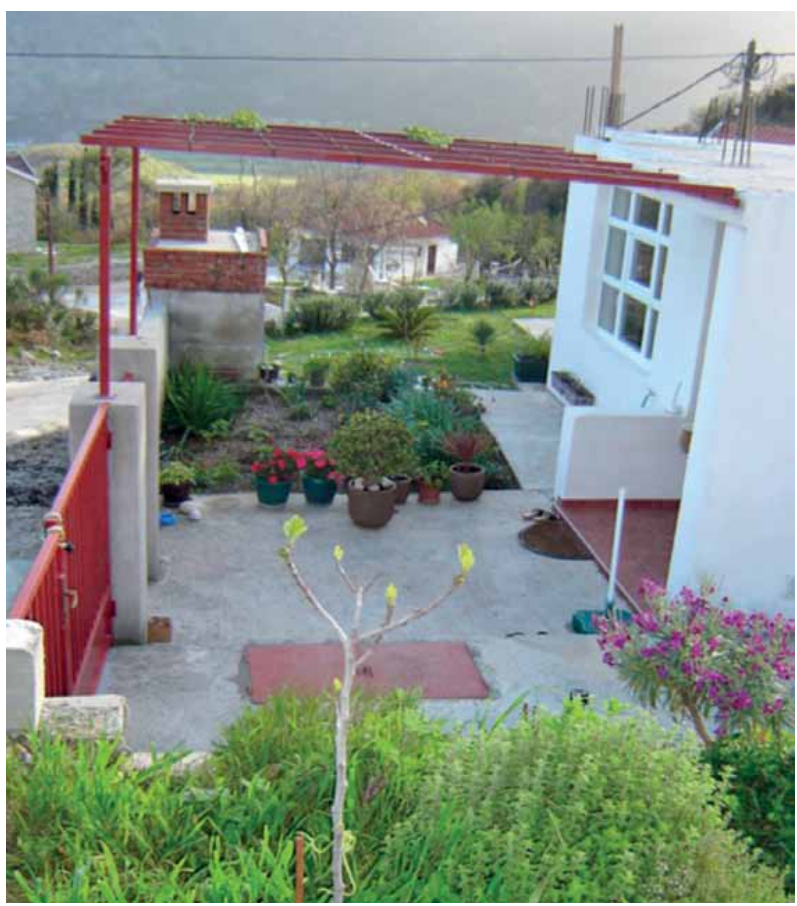

Fig. 13. Local Residence as deemed by local government and planning policy, and what is regarded as useful and practical by the local stace holder. This is illustrative of local planning policy - ecology seen as an aesthetic addition to spatial development in contrast to the more practical application local vegetation and horticulture. In practice the local resdident exeded the number of trees required by planting mostly fruit trees and by substituting the area required to be covered with shrubs by cultivating vegetable beds. The structure of the house conforms to local building practices and is of standard re-enforced concrete construction and will be completed (in common with local practice) with a terracotta-tiled roof. The suggested (local planning) vegetation is for most part decorative such as conifer and palm trees. Though the choice of recommended species is designed to blend into the local landscape and is relatively eco friendly, it fails to take into account any economic viability related to actualising sustainable practice.

Accordingly, the house owner by adding to the recommended planting plan by planting olive and fruit trees (Figs 13 and 14) and expanding the green space (Fig. 15) and also by propagating seasonal vegetables she has created a multifunctional green space. This example of individual initiative whilst not necessarily driven by the desire to conform to the objective of contributing to the notion of the 'eco-state' is nevertheless a valuable contribution to sustainable development in the region.

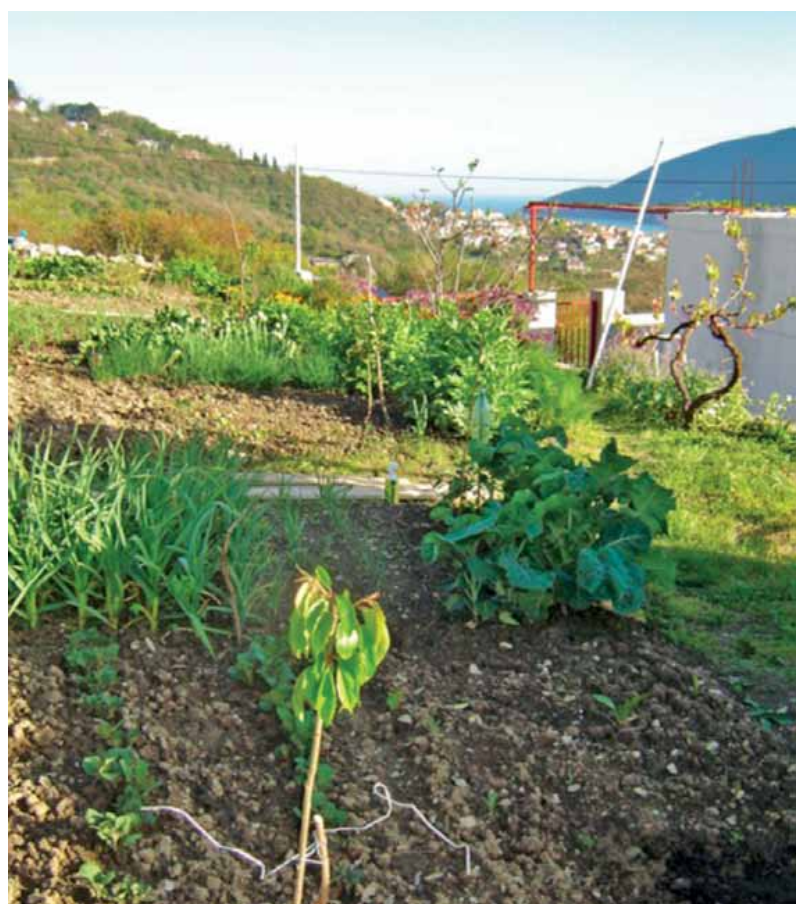

Fig. 14. House Garden 


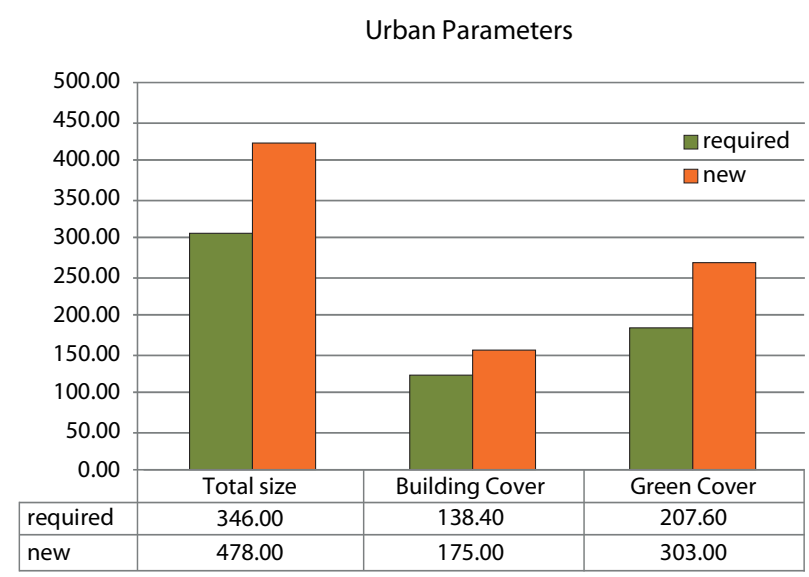

Fig. 15. Planting Requirement and Implementaion

This communal and self-sufficient approach to implementing and creating green space is a more ecologically inspired response to the expansion of urban centres. This illustrates that with encouragement and a more imaginative adoption of ecological principles within the planning process individuals can be encouraged to adopt viable ecological principles as a matter of course. In the case of this resident she expressed a level of frustration concerning the following issues:

- Feeling obliged to buy expensive palm trees when she could grow her own local species from cuttings.

- No governmental incentives for alternative energy sources.

- Post-planning hidden application costs for apparently inconsequential services, subsequently draining allocated construction funds.

\section{Conclusions}

Montenegro is in a state of transition with many of the issues associated with change over a relatively protracted time span being condensed into a compacted time period. Generally, the commitment demonstrated to effect sustainable evolution within the economy, environment and constitution should be positively acknowledged. In many respects this progress is facilitated and monitored by foreign involvement in the affairs of Montenegro. The EU plays a pivotal role in establishing parameters and the required necessary discipline as defined by the MIDP in establishing and realising objectives. The $\mathrm{UN}$ is also an influential arbiter, particularly its role in attempting to empower Montenegro to become an 'eco-state' in reality, not solely as a marketing strategy. The establishment of the 'Green Star' awards and the situating of Aarhus Centre in Podgorica (Montenegro's capital) are tan- gible confirmation of the commitment to achieving bona fide sustainable growth and a pro-active instance of ecologically viable environmental planning.

There are however issues that need to be addressed, in particular aspects of environmental management. NGO's have the impression that "legislation could be much faster". They regard the practice of being paid to draft specific laws as effectively incentivising the production of piecemeal legislation. They also criticize the inspection system noting that inspectors have no "philosophy" on implementation and although there is some level of environmental impact expertise at state levels this is not evident at a local level (Regional Environment Network for Accession 2011). The concern over ineffective governmental sectors is echoed by the UNDP who note that if "the government fail to harmonize the data and their presentation systems the consequences for sustainability can be serious" (UNDP 2008). The biggest unknown variable in the desire to implement sustainable procedures and successful outcomes is corruption. This issue is repeatedly raised within reports on matters ranging from petty bribery to systematic practice within governmental departments (Galbraith 2006). Though this is of concern many of the framework laws concerning environmental policy and law are in place, though the absence of the adoption and implementation on the ground is lacklustre (Regional Environment Network for Accession 2011).

The case studies illustrate many of the issues connected with the implementation of knowledge-based solutions, particularly the disparity between policy and practice. Gary Spence, the construction director for Porto Montenegro explained that the development is "one of the few sites in Europe that is focussed on open minded and sustainable development" (Adam Consultancy 2010). Whilst Porto Montenegro does apply some sustainable principles within the architecture and landscape design features its principles relate more to Article 59 of Montenegro's constitution, which guarantees the freedom of entrepreneurship. The adoption of authentic vernacular design principles is absent and the literary references to vernacular design solutions is misguided. Whether the influx of wealthy foreigners will create a trickle down economic effect will be judged in the fullness of time. However, at present Tivat remains an essentially economically depressed town surrounding a somewhat incongruous gated community that on the face of it does little promote "economically viable" and "socially inclusive" sustainable practice.

At the other end of the ecologically inspired tourist enterprises, the Eco camp is a point of reference for 
a more inspired approach to the aspiration of 'Wild Beauty' and a more vernacular approach to spatial development. Their criticisms of the local governmental attitudes to innovation resonate with the specific issue of 'lack of philosophy' regarding the sustainable environment, but also endemic petty corruption. This frustration with local inclinations runs parallel to experiences of the local resident. Both demonstrate genuine commitment to a more nature inspired development of the urban and rural landscape and have much to offer regarding good practice individually and also at a community level. The key to creating a more vernacular sustainable philosophy is of course through education. If developments like Porto Montenegro are held up as bastions of sustainable development there is no incentive for the creation of any meaningful adoption of ecological principles within the local population. If the local residents see sustainable ecological practice as being economically beneficial as our local case study identifies, the likelihood of acceptance of pragmatic sustainable practice as a lifestyle choice is more feasible and more in keeping with the notion of the 'eco-state'. Inevitably this means some level of funding for local ventures and a willingness from the government to demonstrate a commitment to alternative methods of sustainable technology and communal initiatives that could actually contribute to the notion of 'Wild Beauty'. If Montenegro learns anything from its history it should once more learn to embrace radical ideas from pioneering foreigners as well as ticking the boxes established by the foreigners in Brussels.

\section{References}

Adam Consultancy. 2010. Porto Montenegro [online], [cited 26 October 2010]. Available from Internet: http://www. adamconsultancyuk.com/upload/Porto\%20Montenegro \%20-\%20information.pdf

Anholt, S. 1998. Nation-brands of the twenty-first century, Journal of Brand Management 5(6): 395-406.

Balkans.com. 2012. Montenegro's economy will not grow in 2012 [online], [cited10 April 2012]. Available from Internet: http:// www.balkans.com/open-news.php? uniquenumber $=138242$

Benner, J.; Eichhorn, T.; Krause, K.; Muller, Y. 2008. MonPlanGML - GML-based data model for municipal land management in montenegro, in Real Corp 2008 Proceedings, 19-21 May, 2008, Tagungsband, Vienna.

Bickert, M.; Goler, D.; Lehemeier, H.; 2011. Coastal tourism in Montenegro - economic dynamics, spatial developments and future perspectives, Hrvatski Geografski Glasnik 73(1): $165-180$.

Bloomberg Businessweek. 2011. Porto Montenegro, the Balkan Riviera [online], [cited 12 October 2011]: Available from internet: http://www.businessweek.com/magazine/ content/11_17/b4225081076010.htm
Centre for Alternative Technology (CAT). 2010. SmallScale Sewage Treatment and Composting Toilets [online], [cited 15 March 2012]. Available from internet: http://info.cat.org.uk/sites/default/files/documents/ SewageTreatmentAndCompostToilets.pdf

Commission Implementing Decision on a Multi- annual Indicative Planning Document (MIPD) 2011-2013 for Montenegro, COM (2011) 8220, final.

Commission Decision on a Multi-annual Indicative Planning Document (MIPD) 2007-2009 for Montenegro, COM (2007) 2269, final.

Constitution of Montenegro. 2007. Official Gazette of Montenegro, October, 2007 [online], [cited14 May 2012]. Available frim Internet: http://www.wipo.int/wipolex/en/ details.jsp?id=6920

Constitution of the Republic of Montenegro. 1991. The Secretariat of Information of the Republic of Montenegro, Bozidar Jaredic, Podgorica.

Corner, J. 2007 Terra Fluxus, in C. Waldheim (Ed.). The landscape urban reader. New York: Princeton Architectural Press.

Derbyshire, A. 2011. Sustainable urban habitats: design intentions to practical implementation, Urban Design and Planning 164(1): 19-28.

Derbyshire, A. 2010. Do architects draw trees? - Shifting the perception of urban landscape form, Journal of Sustainable Architecture and Urban Development 2: 67-79. CSAAR.

EStandardsForum. 2010. [Online], [cited 25 June 2013]. Financial Standards Foundation, New York, NY. Available from Internet: www.estandardsforum.org

Galbraith, A. L. 2006. Corruption in Montenegro, Untying the Knot [online], [cited $12 \mathrm{March}$ 2012], Available from Internet: http://digitalcollections.sit.edu/isp_ collection/605/

Graburn, N. 1995. Tourism, modernity and nostalgia, in A. S. Akbar, C. N. Shore (Eds.). The future of anthropology: its relevance to the contemporary world. London, Atlantic Highlands, NJ: Athlone, 158-178.

Heath, K. W. 2007. Assessing regional identity amidst change: the role of vernacular studies, Perspectives in Vernacular Architecture 13(2): 76-94.

Hough, M. 1984. City form and natural process. London: Croom Helm.

Hough, M. 1990. Principles for regional design, from out of place: restoring identity to the regional landscape. New Haven CT: Yale University Press.

Kapetanovic, A. 2006. Restoration of a Traditional Montenegrin Stone House, Expedito Center for Sustainable Spatial Developmen, Expeditio.

Kazimee, B. A. 2008. WIT Transactions on Ecology and the Environment, vol. 113. WIT Press.

Kingsmill, C. 2011. Destination Porto Montenegro, The Porto Montenegro Magazine, Issue 1(Spring) 2011.

McCall, R. 2011. Porto Montenegro: from naval base to superyacht marina superyacht times. Available from internet: http:// www.superyachttimes.com/editorial/12/article/id/5605

McHarg, I. 1997. Why is architecture oblivious to the environment, in C. Zelov, P. Cousineau ( Eds.). Design outlaws on the ecological frontier. New Jersey: Knossos Publishing, 54-57.

McHarg, I. 1967. Design with nature. London: John Wiley \& Sons. 
Nedovic-Budic, Z.; Cavric, B. 2006. Waves of planning: a framework for studying the evolution of planning systems and empirical insights from Serbia and Montenegro, Planning Perspectives 21: 393-425.

http://dx.doi.org/10.1080/02665430600892146

NSSD. 2007. National Strategy of Sustainable Development of Montenegro [online], [cited 12 February 2012]. Available from Internet: http://www.kor.gov.me/files/1207655097.pdf

Oliver, P. 2007. Dwellings: the vernacular house worldwide. London: Phaidon Press.

Regional Environment Network for Accession (RENA). 2011. Review of Montenegro's Implementation and Enforcement Procedures in the Environment Sector, Country External Assessment Report - Montenegro.

Spatial Plan of Montenegro Untill 2020. 2008. Ministry of Economic Development. [online], [cited 25 November 2011]. Available from Internet: http://www.ada-bojana.info/ docs/Spatial_plan_of_Montenegro_until_2020.pdf

Tivat Borough. 2011. Local environmental Protection Plan [online], [cited 6 April 2012]. Available from Internet: http:// opstinativat.com/cg/images/stories/OBAVJESTENJA/ Urbanizam/5_nacrt plana.pdf

The Constitution of Montenegro. 2007. The Constitutional Law for the Implementation of the Constitution of Montenegro [online], [cited 12 February 2012]. Available from Internet: http://www.comparativeconstitutionsproject.org/files/ Montenegro_2007.pdf

Thomas, L. 2010. Montenegro reaches for respectability with port, New York Times, 18 August, 2010.

United Nations Development Program. 2006. Assessment of Development Results Montenegro [online] [cited 25 November 2011]. Available from Internet: http://www.undp. org.me/about/ADR.pdf

United Nations Development Program. 2008. Evaluation of the Economy and Environment Cluster of UNDP Country Office in Montenegro [online], [cited 25 November 2011]. Available from Internet: http://www.undp.org.me/files/reports/ee/ External\%20evaluation\%20of\%20the\%20EE\%20cluster\%20 UNDP\%20CO\%20Montenegro\%202009.pdf

US - Montenegro Business Council. 2012. Tourism Economic Sector in Montenegro [online], [cited 12 September 2012]. Available from Internet: http://www.usmnebc.org/node/22

Vitic, A.; Ringer, G. 2007. Branding post-conflict destinations: recreating Montenegro after the disintegration of Yugoslavia, Journal of Travel and Tourism Marketing 23(2/3/4): 127-137.

Vuksanovic, D. 2006. Architectural Atlas of Montenegro [online], [cited 10 September 2012]. Available from Internet: http://www.gov.me/files/1247231246.pdf

$\mathrm{Wu}$, J. 2008. Making the case for landscape ecology, Landscape Journal 27(1): 41-50. http://dx.doi.org/10.3368/lj.27.1.41

\section{ALAN DERBYSHIRE}

University of Central Lancashire, UCLan, Preston, PR1 2HE, UK. E-mail: akderbyshire@uclan.ac.uk

Alan Derbyshire is presently a Senior Lecturer in Design at the University of Central Lancashire, U.K. He divides his time between academia and professional practice and is currently involved with a number of live projects relating to resilient eco-living in emerging regions.
His most recent project involves appraising the impact of urban expansion on communities in Montenegro, monitoring cultural variables; local resources and environmental conditions with the objective of identifying innovation and good practice. As such, he was awarded the prestigious Reed and Mallik Medal from the Institute of Civil Engineers for best research paper on the subject of Urban Design in their Published Journals in 2012.

\section{TATJANA KECOJEVIC}

University of Central Lancashire, UCLan, Preston, PR1 2HE, UK. E-mail: tkecojevic@uclan.ac.uk

Tatjana Kecojevic is presently a Senior Lecturer in Quantitative Modelling in Lancashire Business School at the University of Central Lancashire, U.K.

Tatjana's research work has helped to develop her knowledge and skills within the area of applied statistical modelling, and in particular within quantile regression modelling, which is now regarded as a practical tool for researchers. Her current projects include developing graphical data interfaces for resilience assessment in architecture and urban form. As such, the area of her research enhances the opportunities for cross discipline research projects within the built environment. 